\title{
THE QUALITY OF THE DECISION-MAKING PROCESS IN ROAD TRANSPORT
}

doi: 10.2478/cqpi-2019-0012

Date of submission of the article to the Editor: 13/04/2019

Date of acceptance of the article by the Editor: 21/05/2019

Robert Sałek - orcid id: 0000-0002-5416-9448

Czestochowa University of Technology, Poland

\begin{abstract}
The issue of quality is a very important aspect of the operation of transport companies. In relation to the area of their activity it primarily focuses on the quality of services provided, which can be verified e.g. on the basis of timeliness of deliveries or accepted complaints. This allows for examining the quality after providing the service in order to take future pro-quality actions. However, is it possible to affect the quality of services provided before their provision? The transport process itself is preceded with a range of actions taken within the framework of detailed planning and organization, which can significantly influence the quality of services. The decisions made at the management level are conditioned by many factors determining the course of future events, however, this is not always enough to make the process run uninterruptedly. Therefore, it is important to structure basic actions at the initial stage so as to allow the smooth conduct of the decision-making process for the specific task in order to subsequently focus on the detailed analysis of the actions planned. In the paper, the author attempts to characterize the fundamental factors affecting the decisions taken during the planning and organization of the transport process. The objective of the conducted research is to verify initial decisions and their significance for the improvement in the quality of transport services provided. There was conducted the algorithmization of actions and interpretation of their importance for the quality of decisions taken at the preparatory stage and during transport.
\end{abstract}

Keywords: Transport, quality, decision-making processes, management

\section{INTRODUCTION}

Road transport as one of the areas of the national economy is usually the factor dynamizing its development, all departments of production of tangible goods and services. It constitutes the most important mechanism for satisfying the needs of trade in goods, modelling spatial order or development of economic entities. The production nature of transport determines the fact of its contributing to generation of the national income (Mendyk, 2009). In economic terms, logistics costs are estimated at the level of $11 \%$ of gross domestic product (GDP), where road transport amounts to $30-66 \%$ (Ballou, 2007). According to the Central Statistical Office (GUS), transport companies generate $5.8 \%$ of the total GDP of Poland nowadays. This puts transport in the third 
position in terms of contribution to GDP, just after industry and trade and before construction. In accordance with the aforementioned data, the industry in Poland employed 345 thousand people, with an upward trend. Nearly 33 thousand Polish transport companies actively participate in freight transport in Europe. In 2017 the volume of freight transport by road expressed in tkm amounted to $17.5 \%$ whereas the share of Polish companies in international transport amounted to over $30.7 \%$, which, in both cases, ranks Poland in the first position among the countries of the European Union (GUS, 2017).

An increase in the area of freight transport by road is also a problem and a challenge in terms of ensuring its sustainable development. Undoubtedly, the impact of road transport on the environment is large. In their work, (Campos et al., 2019) give reflections of the issue of sustainable transport, identifying economic, environmental and social factors in order to develop the method assessing its impact in all three dimensions. The authors list, among others, operating costs as one of the economic factors. They affect the cost of transported freight and amount to $10-20 \%$ of the total cost of the product. The activity of companies providing transport services includes the evaluation of operating costs for each carriage planned, which justifies the impact of decision-making on the total cost of the product. The complexity of actions taken within the framework of planning and organization of freight transport requires the thorough analysis of all activities formulating the future decision. They are the basis for the formulation of solutions for problems in the decision-making process (Meissner and Wulf, 2014). The paper contains the analysis of the decision-making process based on the data obtained from the company providing transport services in the area of the district of Kłobuck in the Silesian Voivodeship. The information acquired was the basis for the development of the decision-making algorithm and determination of the total cost of an exemplary transport process.

\section{THE QUALITY OF DECISIONS AND DECISION-MAKING PROCESSES}

Taking decisions, particularly managerial ones, is a daily, routine activity but also a complex one, requiring a lot of work associated with acquiring information, data quality and risk assessment (Günther et al., 2019). Decision-making, making choices, is a fundamental managerial activity which is performed regardless of the rank in the hierarchy or type of activity (Weiss, 2008). Decision-making consists of the absolutely orderly successive stages. To implement each of them a lot of new and already collected data and information are required. Three basic stages can be identified (Markowski, 2012; Więcek-Janka, 2011; Ziuziański and Furmankiewicz, 2015):

a. Recognizing the decision-making problem - identifying the causes, effects and its possible solutions (observing reality, assessing the situation in economic, technical and organizational terms, collecting information on the problem, determining the scope of the problem).

b. Designing the decision - establishing the criteria and decision-making measures on the basis of which decision-making options will be subsequently developed (defining the criteria, identifying possible benefits from making choices, developing alternative solutions, selecting an optimal solution).

c. Making a final decision - selecting the best of the available alternatives by assessing the relationships between the available options to choose from, i.e. in accordance with the criteria established (selecting the best option, access to human and tangible resources, preparing the work schedule and the plan of 
implementation of individual tasks, testing the efficiency of operations, possible correction of assumptions in order to increase the overall effectiveness of actions taken).

The efficient decision-making process requires the reliable preparation of participants and possessing current information on the problem. Davern et al. in the work on diagnosing the quality of decisions, indicate new methodological observations in the area of the quality of decisions taken. They focus on two aspects: identifying systematic strengths and weaknesses in the decision-making process, improving the efficiency of decisions through acquiring information on the specific problem more easily. Individual stages of the general methodology are presented in Table 1.

Table 1

General methodology of diagnosing decisions

\begin{tabular}{|l|l|l|}
\hline \multirow{2}{*}{ Stage } & \multicolumn{2}{c|}{ Diagnostic step } \\
\cline { 2 - 3 } I & \multicolumn{1}{|c|}{$\mathbf{c}$} & \multicolumn{1}{c|}{$\mathbf{2}$} \\
\hline Issessment & $\begin{array}{l}\text { Identification of portfolio of } \\
\text { performance measures, the } \\
\text { corresponding comparative } \\
\text { indicators and external } \\
\text { variables. }\end{array}$ & $\begin{array}{l}\text { Construction of a classification tree in } \\
\text { order to facilitate the separation of } \\
\text { systematic decision effects from } \\
\text { external/random fluctuations of the } \\
\text { results. Classification of decision } \\
\text { outcomes. }\end{array}$ \\
\hline II Diagnosis & $\begin{array}{l}\text { Interpretation of the results of } \\
\text { the classification process, } \\
\text { analyzing the distribution of } \\
\text { decision outcomes in diagnostic } \\
\text { classes in a decision tree. }\end{array}$ & $\begin{array}{l}\text { The analysis of results in diagnostic } \\
\text { classes, identifying potentially relevant } \\
\text { variable clues and constructing control } \\
\text { charts in order to quickly discover causal } \\
\text { explanations of systematic patterns. }\end{array}$ \\
\hline
\end{tabular}

Source: based on Davern et al. 2008

The objective of the first stage is to assess the efficiency of decisions. Efficiency is treated as a reference to the quality of decisions and not the results. In practical terms, the result is dependent on the environment (external factors) and the decisionmaker (internal factors). For this reason, the quality of the results is stochastically related to the quality of the decisions taken. The second stage is to identify systematic strengths and deficiencies in the decision-making process. It focuses on the information on functional importance as well as the information on specific tasks. The information should relate to guidelines which are inappropriately evaluated by the decision-maker in order to be the most effective in streamlining the efficiency of decisions (Davern et al. 2008). The optimal level of service quality in the supply chain mainly depends on the degree of involvement for individual participants at any stage (Nowicka-Skowron and Ulewicz, 2015). In the current global economy, the planning and organization of transport processes using traditional methods is no longer possible. The planners are oriented to the use of modern solutions in order to improve the quality and rapidity of decision-making. The development of science provides increasingly new tools and methods, such as: artificial intelligence, optimization algorithms, statistical analyses, information processing centers (Big Data, Business Intelligence (Kościelniak and Puto, 2015; Jelonek et al., 2019)), GIS, GPS, comprehensive telematics solutions or intelligent transport systems (ITS), which support decision-making processes at each stage. (Ocalir-Akunal, 2016). 


\section{THE QUALITATIVE ANALYSIS OF THE DECISION-MAKING PROCESS}

\subsection{The entity under research}

The entity under research was a small company providing transport services with the headquarters in the area of the Silesian Voivodeship. The information presented was provided by the company's owners. At their request, the name of the entity cannot be disclosed. The company mostly deals with express transport nowadays, in the area of Europe, these are mainly the countries of Western Europe, such as: Germany, France, Belgium, the Netherlands, Great Britain, Spain. These services relate to direct carriages dedicated to and implemented in the system of ASAP (As Soon As Possible) and JIT (Just In Time). The company uses the integrated IT system. This system was designed and made at the company's request and its task is to integrate all the departments, from cost registration through management of transportforwarding orders, the warehouse, service to after-sales document service. The system also enables an instant access to and insight into the course of the transport process for the ordering customer. They have insight into the current geo-location of the vehicle or e.g. the expected time of delivery. The system sends a notification to the customer in case of the occurrence of problems and disturbances during transport.

\subsection{The analysis of activities in the decision-making process}

The activities associated with planning and organization of transport are the key element of the operation of the company providing transport. The efficient organization of the transport process translates into profit. In the analyzed case, the transport process itself is preceded by a number of organizational and decisionmaking activities resulting in the performance of transport in accordance with the assumptions of time and cost. It is necessary to classify the structure of the whole process, in which three main stages are identified:

- Analysis and development of the process input factors.

- The actual transport process (freight transport).

- Output parameters, operations ending the whole process.

The most demanding and labor-intensive is the first stage analyzed in most detail. During this stage it is aimed to accept the transport order by both interested parties, the ordering party and the carrier. The initiating factor is the enquiry sent by the customer relating to the valuation and the possibility of organization of transport of the specific load on the specific route according to the requirements specified in the query. The customer is obliged to specify the data concerning the transport of the specific load: place of loading and unloading, time of loading and unloading, quantity and form of goods, gross weight of the load, information on the load value, possible special requirements. After obtaining the information, decision-makers conduct a detailed analysis of the request for quotation following the developed pattern by taking the subsequent steps:

- controlling the ordering party (checking in terms of financial arrears, checking the National Debt Register - KRD),

- determining the ability to provide transport (availability of the vehicle in the specific location, analysis of the time of loading in relation to the distance to the vehicle),

- determining the transport route (software and digital maps), 
- verifying the possibility of providing transport (determining the optimal transport route and calculating the time of the transport operation),

- calculating the cost of the service (specifying the freight rates, determining the total cost of the order fulfillment),

- generating the order (price negotiations, assigning the vehicle, information for the driver, assigning the access to the information platform for the customer),

- loading of goods (information for the customer),

- supervising the service fulfillment (the transport is supervised by the dispatcher using the telematic system - the vehicle position and the expected time of delivery),

- confirming the service fulfillment (unloading of goods, confirming the delivery, the digital copy of the certified bill of lading (POD) transmitted electronically to the customer, issuing the invoice for the provided transport service, complaints).

\subsection{Operating costs of the transport process}

The calculation of the cost is a complicated process, mainly due to the complexity of the activity which transport is. Many cost items should be taken into account, however, the cost of each route is formed differently, taking into account the need to pay a minimum wage in line with the provisions of the country in which the driver works. Determination of costs begins with determination of fixed costs of vehicle operation per month and is expressed in Polish zloty per kilometer (PLN/km). For the purposes of the calculations, the average mileage of the vehicle per month was assumed, which, on the basis of historical data, amounts to $15000 \mathrm{~km}$ per month. Fixed costs are presented in Table 2. They result from the data and documentation of the company available for the purposes of the research.

Table 2

Fixed costs incurred by the entity under research

\begin{tabular}{|l|l|}
\hline \multicolumn{1}{|c|}{ Cost type } & Amount in PLN/month \\
\hline Leasing & 3700 PLN (net) \\
\hline Telephone subscription & 90 (net) \\
\hline Telematic subscription & 120 (net) \\
\hline Depreciation & 500 \\
\hline Driver's basic salary/Employer's charges & 6110 \\
\hline Legal protection & 150 (net) \\
\hline Insurance & 670 \\
\hline Costs of administrative services & 200 \\
\hline Total fixed costs $\left(\mathrm{K}_{\mathrm{s}}\right)(11540 \mathrm{PLN} /$ month $) /(15000 \mathrm{~km} /$ month $)$ & $0.77 \mathrm{PLN} / \mathrm{km}$ \\
\hline
\end{tabular}

Source: Own calculation based on company's data

The driver's (basic) salary due to the employment relationship amounts to: PLN 5070 gross, which, with an average amount of 160 man-hours per month gives 31.68 PLN/hour. Variable costs of an exemplary transport operation are presented in Table 3. The total costs of the analyzed transport $(\mathrm{K})$ can be determined as:

$\mathrm{K}=\mathrm{K}_{\mathrm{s}} \times 1584+\mathrm{K}_{\mathrm{z}}=(0.77 \mathrm{PLN} / \mathrm{km} \times 1584 \mathrm{~km})+\mathrm{PLN} 1576.78=\mathrm{PLN} 2796.46$

The company assumes the profit of $15 \%$ of the costs, which gives the final cost of the transport implementation: PLN $2796.46 \times 115 \% \approx$ PLN $3216\left(\frac{3216 P L N}{1584 \mathrm{~km}}=2.03 \mathrm{net}\right)$. 
Table 3

Variable costs for the analyzed transport

\begin{tabular}{|c|c|}
\hline Cost type & Amount in PLN \\
\hline $\begin{array}{l}\text { Fuel costs }+ \text { AdBlue }=\frac{12 l}{100 \mathrm{~km}} \times 1584 \mathrm{~km}=190 \mathrm{l} \times 5.23 \frac{P L N}{l} \text { (net) } \\
\text { determined on the basis of the data shared by the company }\end{array}$ & 994 \\
\hline $\begin{array}{l}\text { Tolls: The A4 motorway in Poland (calculated on the basis of www.viatoll.pl). } \\
\text { tolls in France: } 120 \text { Euro } x 4.30 \mathrm{PLN}^{*} \text { (calculated on the basis of } \\
\text { www.autoroutes.fr) *the average euro exchange rate }\end{array}$ & $\begin{array}{l}15.10 \\
516\end{array}$ \\
\hline $\begin{array}{l}\text { Costs of minimum wages in the area of Europe: } \\
\text { Germany - excluded due to a transit journey } \\
\text { France: *the euro exchange rate according to Loi Macron amounts to } 1 \text { EUR = } \\
4.29001 \text { PLN } \\
{\left[4.75 \mathrm{~h} \times\left(9.92 \frac{\text { EUR }}{\text { hour }} \times \mathrm{PLN} 4.29001\right)\right]-\left(31.68 \frac{P L N}{\text { hour }} \times 4.75\right)=\left(4.75 \times 42.56 \frac{\text { PLN }}{\text { hour }}\right)-} \\
\text { PLN } 150.48=\text { the pay subsidy for the driver }\end{array}$ & 51.68 \\
\hline Total variable costs $\left(\mathrm{K}_{\mathrm{z}}\right)$ for the analyzed transport & 1576.78 \\
\hline
\end{tabular}

Source: Own calculation based on company's data

The above calculations are the transparent determination of the cost which the company will have to incur while implementing the analyzed freight. When calculating freight rates, which must be made as soon as possible and immediately sent to the customer, the use of a computer program dealing with the detailed working time account is impossible, mainly due to the time-consuming nature of data preparation. The company makes calculations in the manner presented above. This allows the determination of the price in the short term.

\subsection{Formation of the decision-making algorithm}

As a result of the analysis of work organization of the company and on the basis of the interview with the company's managers, the graphic presentation of the operations was developed (Figure 1).

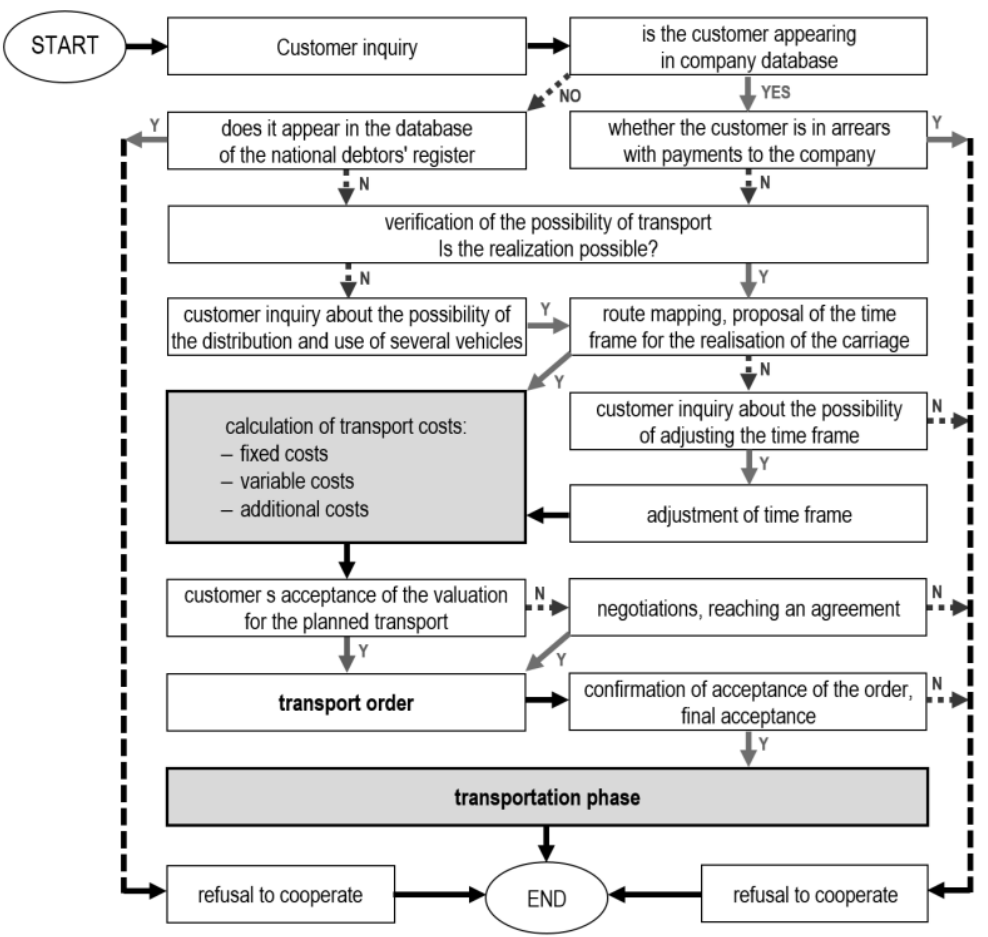

Fig. 1. Decision algorithm for planning and organizational operations (Own study) 
There is presented the decision tree, developed on the example of actions taken during planning and organization of the transport process. The use of the decision tree for this type of operations is a significant facilitation in terms of structuring of individual actions in the decision-making process.

The developed operation chart was divided into two parts. The first one relates to the actions which must be taken before the implementation of transport whereas the other one refers to the implementation of transport itself and actions taken after transport is completed (Figure 2.).

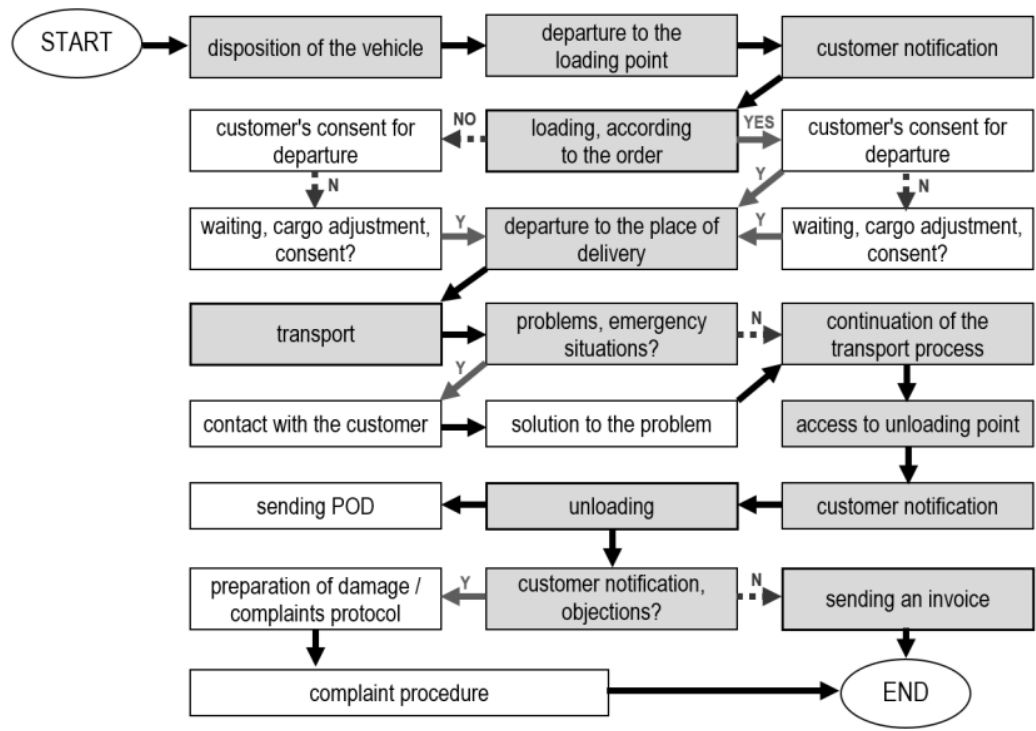

Fig. 2. Decision algorithm for implementation of transport (Own study)

The company, using the presented algorithms of decision-making, will receive the tool optimizing the decision-making process. The use of the presented tool and, at the same time, the storage of records concerning the price calculation will also allow for effective archiving and the possibility of insight into the process of making the specific decision concerning the transport creating a problem or the profitability of which raises objections among managers.

\section{CONCLUSION}

The paper contains the analysis of the decision-making process observed during the organization of freight transport by road by the surveyed entity. The process of transport planning was discussed, which allowed the illustration of its complexity, and subsequently the analysis of individual components while revealing the complexity of taking such decisions. The calculation of transport costs was also presented while indicating the complexity of system of remuneration of drivers in the international transport sector, at the same time pointing out what legislative problems entrepreneurs across Europe must encounter. After recalling all elements of the decision-making situation associated with transport planning, the action plan while taking decisions was presented. As the streamlining of the discussed decision-making process, decisions trees were suggested, illustrating in detail, step by step, the actions which the decision-maker should take in order to significantly reduce the risk of taking wrong decisions. The suggested decision trees may be implemented by the entity under research, which will enable the coordination of the decision-making 
process by the appointed and responsible people and not only by owners. The previously indicated decisions were taken by owners due to high risk these decisions were burdened with. The suggested solution will definitely streamline the process of decision-making but also improve the control over transport organization.

\section{REFERENCES}

Ballou, R.H., 2007. Business logistics/supply chain management, 5 Ed, Pearson Education India.

Campos, R.S., Simon, A.T., Campos Martins, F., 2019. Assessing the impacts of road freight transport on sustainability: A case study in the sugar-energy sector, Journal of Cleaner Production, Vol. 220, 995-1004, doi.org/10.1016/j.jclepro.2019.02.171

Davern, M.J., Mantena, R., Stohr, E.A., 2008. Diagnosing decision quality, Decision Support Systems, Vol. 45, Issue 1, 123-139, doi.org/10.1016/j.dss.2007.12.012

Główny Urząd Statystyczny, 2018. Transport wyniki działalności w 2017r., Warszawa, Szczecin.

Günther, L.C., Colangelo, E., Wiendahl, H.H., Bauer Ch., 2019. Data quality assessment for improved decision-making: a methodology for small and mediumsized enterprises, Procedia Manufacturing. Vol. 29, 583-591, doi.org/10.10 16/j.promfg.2019.02.114

Jelonek, D., Stepniak, C.J., Ziora, L,. 2019. The Meaning of Big Data in the Support of Managerial Decisions in Contemporary Organizations: Review of Selected Research, [in:] Arai, Kohei, Kapoor, Supriya, Bhatia, Rahul (Eds.) Advances in Information and Communication Networks, Vol. 886, (FICC), Vol. 1, 361-367, Springer International Publishing 2019, DOI:10.1007/978-3-030-03402-3_24

Kościelniak, H., Puto, A., 2015. BIG DATA in decision making processes of enterprises, Procedia Computer Science, Vol. 65, 1052-1058, doi: 10.1016/j.procs.2015.09.053

Markowski, E., 2012, Intuicja jako czynnik wspomagający proces podejmowania decyzji w warunkach ekstremalnych, [in]: Harasim, W., (ed.), Zarządzanie kapitałem intelektualnym w organizacji inteligentnej, Wyższa Szkoła Promocji, Warszawa.

Meissner, P., Wulf, T., 2014. Antecendents and effects of decision comprehensiveness: The role of decision quality and perceived uncertainty, European Management Journal, Vol. 32, Issue 4, 625-635, https://doi.org/10.1016/j.emj.2013.10.006

Mendyk, E., 2009. Ekonomika transportu, Wyższa szkoła logistyki, Poznań.

Nowicka-Skowron, M., Ulewicz, R., 2015. Quality management in logistics processes in metal branch, "METAL 2015“, 24th International Conference on Metallurgy and Materials, June 3-5, Brno, Czech Republic.

Ocalir-Akunal, E.V., 2016. Decision Support Systems in Transport Planning, Procedia Engineering, Vol. 161, 1119-1126, doi.org/10.1016/j.proeng.2016.08.518

Weiss, E., 2008. Podstawy i metody zarządzania. Wybrane zagadnienia, Wyższa Szkoła Finansów i Zarządzania w Warszawie, Warszawa.

Więcek-Janka, E., 2011. Podejmowanie decyzji w mikroprzedsiębiorstwach rodzinnych, Studia i Prace Kolegium Zarządzania, nr 116,184-196.

Ziuziański, P., Furmankiewicz, M., 2015. Rola kokpitu menedżerskiego w procesie podejmowania decyzji, Zeszyty Naukowe Politechniki Śląskiej, Organizacja i Zarządzanie, $\mathrm{nr}$ 77, 11-321. 